\title{
REDUCING THE EFFECTS OF PLASTIC WASTE IN AGRICULTURAL APPLICATIONS BY DEVELOPING NEW OK SOIL BIODEGRADABLE PLASTICS
}

\author{
${ }^{1}$ AITIIP, Centro Tecnológico, Polígono Empresarium, Zaragoza, Spain \\ ${ }^{2}$ Parque Científico Tecnológico Aula Dei, Zaragoza, Spain \\ ${ }^{3}$ Laboratori ARCHA, Pisa, Italy \\ ${ }^{4}$ Estación Experimental de Aula Dei (EEAD-CSIC), Zaragoza, Spain
}

Carolina Peñalva ${ }^{1, *}$, Marta Pérez ${ }^{2}$, Francesca Braca ${ }^{3}$ and Diego Redondo ${ }^{4}$

Article Info:

Received:

7 January 2020

Revised:

21 May 2020

Accepted:

5 June 2020

Available online:

5 October 2020

Keywords:

Waste agro plastics

Mulching

Fruit protection bags

Biodegradable on soil plastics

\begin{abstract}
Current intensive farming practices require the use of large quantities of mulching film and fruit protection bags since they prevent the growth of weeds, regulate soil temperature, retain water and nutrients and protect crops from insects. These practices use single-use conventional non-degradable polymers which create a serious problem of waste management since this management is time-consuming, expensive to recycle and, more importantly, non-environmentally friendly. By using biodegradable plastics, this problem could be solved by preventing the creation of waste. The objectives of this study were to produce an innovative biobased and biodegradable plastic film that entirely biodegrades in natural conditions on the field within a short time after its usage and to know its effects on tomato and peach crops. For this purpose, two types of films were produced: biomulching and biobags. Specific oligo elements have been added to the films in order to test the biomulching in tomato crops and to protect the fruits from insects and improve quality at harvest in peaches (biobags). Tests carried out on tomatoes showed that, these bioplastics improved soil quality by increasing (up to $13 \%$ ) the concentration of oligo elements and by decreasing (65\%) blossom end rot. By using biobags in peaches, a uniform colour (without red blush), required characteristic in this type of commodity (Protected Designation of Origin 'Calanda'), was obtained, with a decrease in both a* colour coordinate (more than 2 points) and carotenoid content (more than $3 \mu \mathrm{g} \mathrm{g}^{-1} \mathrm{fw}$ ). Moreover, bioplastics degrade completely after 6 months within the soil.
\end{abstract}

\section{INTRODUCTION}

For over a half a century farmers have been using plastic materials in agriculture because of their affordability and their easiness to be applied in the field. The main use of plastics in agriculture is for mulching, and in some Mediterranean areas, for fruit protection bags. The first ones prevent the growth of weeds, regulate soil temperature, and retain water and nutrients which means an increase in yields (Kader et al., 2017). The second ones are single use agricultural bags used in tree crops to protect the fruit from the Mediterranean fly (Ceratitis capitata), the climatic incidences and mainly from chemicals (Sharma et al., 2014).

The convenience of using this type of plastics has made the consumption of plastics grown rapidly in Europe (Mormile et al., 2007). The global market for agricultural plastic films, 4 million tonnes and approximately 10.6 million USD (2015), is projected to grow 5.6\% per year through
2030 (Vitova, 2015). The total consumption in Europe exceeded 500.000 metric tons in 2013 being Spain and Italy the countries with highest consumption, due to their intensive horticulture activities. Together, they account for $40 \%$ of the demand and consume more than 120.000 t per year (Plasteurope.com, 2017).

The main problem of agricultural films is that they have a lifespan of just one cultivation cycle, after which they need to be replaced, which is an intensive, expensive and time-consuming task (Malinconico et al., 2008). The conventional polymers used are non-degradable: LDPE (low density polyethylene) and HDPE (high density polyethylene). The use of this type of plastics create a serious waste management problem since it is time-consuming, expensive to recycle and, more importantly, it is non-environmentally friendly. Furthermore, films are increasingly thinner and often end up being damaged during the cultivation process so they fall apart into smaller pieces, which 


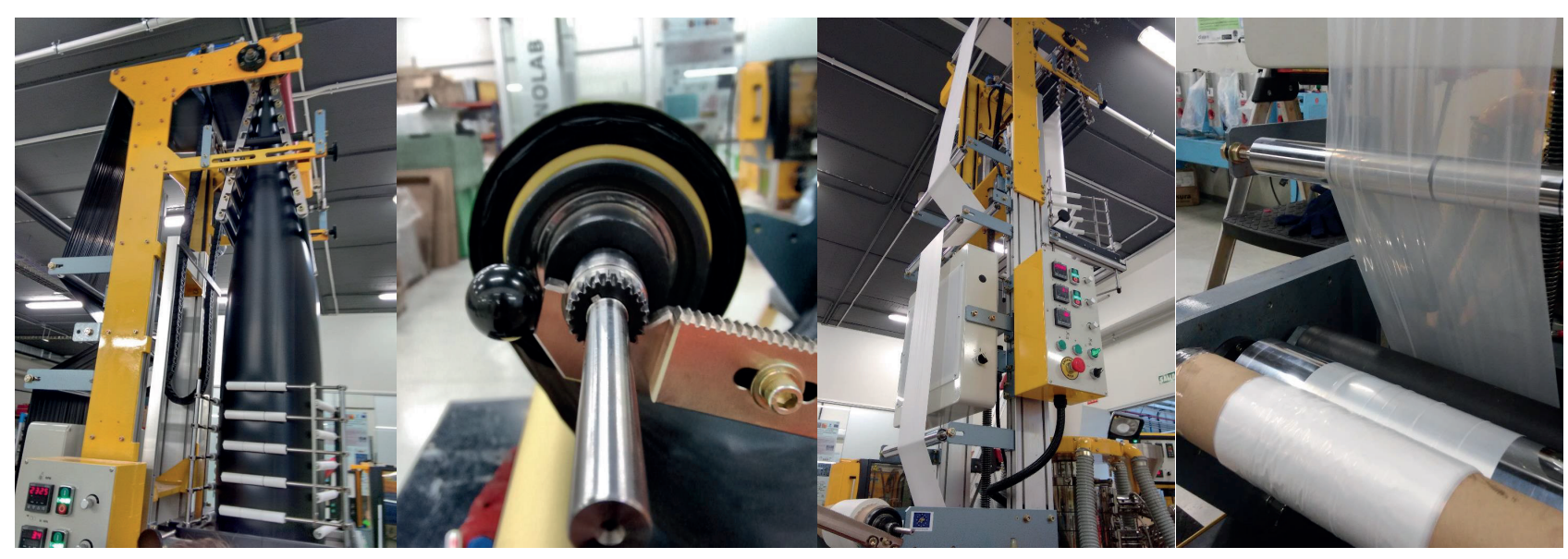

FIGURE 1: Biodegradable agricultural plastics production for mulching and fruit protection bags applications.

complicates the recycling and cleaning up. Approximately only $24 \%$ of mulching film in the European Union gets recycled, while about $50 \%$ ends up in landfills and the rest is incinerated or abandoned in the fields (European Commission, 2014).

By using biodegradable plastics, this problem could be solved by preventing the creation of waste. Biodegradation is a chemical process during which microorganisms that are available in the environment convert materials into natural substances such as water, carbon dioxide and compost within short time lapse. This process depends on the surrounding environmental conditions (e.g. location or temperature), of the material and on the application. According to the International Standard (EN13432), biodegradable plastics are those that are degraded either in 6 months at $58 \mathrm{C}$ (industrial), in 1 year at $28 \mathrm{C}$ (home composting) or in 2 years at $26 \mathrm{C}$ (soil environment).

Over the past few years, international research has carried out many tests to compare soil and crop quality as well as harvest yields between biodegradable films and polyethylene films and they show no differences between them. (Kasirajan \& Ngouajio, 2012, Steinmetz et al., 2016).

Our research focuses on the development of an innovative biobased and biodegradable plastic film that entirely biodegrades in natural conditions on the soil in order to obtain the "OK Biodegradable SOIL" certification (provided by TÜV Austria). This certification ensures that the plastics are entirely biodegradable and not phytotoxic for soil and plants. Furthermore, this study has contemplated the innovation of the addition of certain specific oligo elements ( $\mathrm{Mn}, \mathrm{Zn}$ and $\mathrm{B}$ ) to the mulching films in order to study its effects on the biodegradability and quality of the crops. Additionally, with the use of the biodegradable bags, aims to obtain a homogenous colour and a higher quality peaches which increase their selling price.

\section{MATERIALS AND METHODS}

\subsection{Production of bioplastics}

Biodegradable films were obtained by mixing selected natural biopolymers and additives in a conventional extrusion compounding process (Coperion ZSK26 co-rotating twin-screw extruder, semi-industrial) at AITIIP facilities (Zaragoza, Spain). The compounded materials were afterwards dried (Mini dryers Moretto X DRY AIR T) to ensure a low water level content that could negatively affect film properties. Finally, the blown extrusion machine (LABTECH LBM 125, semi-industrial) equipped with a film module (Type LF-400-COEX) was used to obtain all biodegradable film products (Figure 1).

Samples of mulching and fruit protection bags samples were based on Mater-Bi ${ }^{\mathrm{TM}}$ (corn thermoplastic starch, co-polyester, Novamont S.p.A.), Danimer ${ }^{\mathrm{TM}}$ (PHA/PLA, Meridian Holding Group) and BioPBS ${ }^{\mathrm{TM}}$ (bio-based polybutylene succinate, Japan Pulp \& Paper $\mathrm{GmbH}$ ). All the mulching films were $22 \mu \mathrm{m}$-thick and carbon black was used as a color additive using the masterbatch techniques. In addition, different percentages of oligoelements were added to the samples: $\mathrm{Zn} / \mathrm{Mn}$ complex and Boron. Protection fruit bags were $40-50 \mu$ m-thick and white pigment (PW) was added as bleaching additive in the masterbatch processing.

Due to industrial secret, different concentrations of oligoelements or bleaching agents have been coded as $\mathrm{A}$ for the lowest concentration and $B$ for the highest. Conventional LDPE mulching (Comercial Arnedo, Spain) and conventional waxed paper bags (Cooperative Calanda DO) were used as control samples.

The reference material for biodegradation test is microcrystalline cellulose, produced by ALDRICH, distributed by SIGMA ALDRICH SRL, Code number 310697-500G, Lot number MKBX5118V, Expiration date July 13th, 2022. The average dimension of the particles is $50 \mu \mathrm{m}$,

\subsection{Experimental design}

Three crop seasons (2016, 2017 and 2018) were analyzed for both mulching and fruit protection bags.

For mulching, in the first season 3 different plastics were tested (M11, M21 and M31) with two different concentrations of oligoelements for each plastic (Manganese/ Zinc (codified as A for the lowest concentration and B for the highest)). The mulching films were placed in the field with a separation of $1 \mathrm{~m}$ between lines. In the second season, the sample with lower mechanical performance was 
discarded and different amounts of oligoelements were added (two percentages of $\mathrm{Mn} / \mathrm{Zn}$ and other two percentages of Boron (codified as $A$ for the lowest concentration and $B$ for the highest). Finally, in season 2018, after analysing of the previous results, the best combination selected was material M13 with Boron as oligoelement. A randomized complete block experiment was used to evaluate bioplastics, using three blocks which contain a complete set of bioplastics.

For fruit protection bags, in 2016, three different bioplastics were assayed (B11, B21 and B31) with two levels of added white pigment (coded as $A$ for the lowest concentration and $B$ for the highest). 300 bags per batch were tested and randomly distributed in six blocks. Each block consisted of one tree.

In the second season (2017), the best performance plastic (B12) and a new one (B42) were tested with a reduction in the amount of pigment content (codified as $A$ for the lowest concentration and B for the highest). 500 bags per batch were tested and randomly distributed in six blocks.

In 2018, the best combinations of materials for mulching and fruit protection bags were tested as definite formulations. Table 1 shows the different samples compositions.

\subsection{Vegetables and fruit samples}

For mulching, tomatoes (Solanum lycopersicum 'Manitu') were manually planted (25 May, 2016; 2, June 2017, 4 May, 2018) with a separation between plants of $50 \mathrm{~cm}$. They were harvested randomly from a commercial orchard located in the Mid-Ebro Valley (Zaragoza, Spain) at the time of optimum commercial harvest (25 August, 2016; 31 August, 2017; 28 August, 2018).

For fruit protection bags in peaches (Prunus persica ' $58 \mathrm{GC}$ '), the bags were randomly placed in a commercial orchard located in the Ebro Valley (Calanda, Spain) in the middle of the season (14 July, 2016; 17 July, 2017, 16 July, 2018). Fruits were harvested at optimum commercial harvest (13 September, 2016; 6 September, 2017; 20 Septem- ber, 2018). Both crops were grown under drip irrigation and following the agronomic practices of the area. All samples were transferred immediately to the laboratory to carry out the fruit quality analysis.

\subsection{Characterization Analyses}

\subsubsection{Mechanical properties}

The modulus of elasticity (E) was determined using ISO 604 "Plastics - Determination of Compressive Properties". Elongation at break $(\varepsilon)$ and tensile strength at break $(\sigma)$ were determined by tensile testing in accordance with ASTM D 882 - 12 "Standard Test Method for Tensile Properties of Thin Plastic Sheeting".

\subsubsection{Heavy metals and fluorine concentration of the bio- films}

The concentration of heavy metals was quantified using the EPA 30521996 "Microwave assisted acid digestion of siliceous and organically based matrices" and EPA 6010C 2007 "Inductively coupled plasma-atomic emission spectrometry". Heavy metals are defined in the Standard EN 13432:2000 "Packaging: requirements for packaging recoverable through composting and biodegradation".

The concentration of fluorine was quantified using EN 14582:2016 "Characterization of waste - Halogen and sulfur content - Oxygen combustion in closed systems and determination methods" and EN ISO 10304-1:2009 "Water quality - Determination of dissolved anions by liquid chromatography of ions - Part 1: Determination of bromide, chloride, fluoride, nitrate, nitrite, phosphate and sulfate (ISO 10304-1:2007)".

\subsubsection{Biodegradation tests}

Biodegradation tests were carried out according to ASTM D 5988-12 "Standard Test Method for Determining Aerobic Biodegradation of Plastic Materials in Soil". The tests were performed adding a mixture of three different

TABLE 1: Sample composition of mulching samples (M) and for the fruit protection bags (B).

\begin{tabular}{|c|c|c|c|c|}
\hline \multirow{2}{*}{ Year } & \multicolumn{2}{|c|}{ Mulching } & \multicolumn{2}{|c|}{ Bags } \\
\hline & Material & Oligoelement Level & Material & Colour Level \\
\hline \multirow{7}{*}{2016} & \multirow{2}{*}{ M11 } & M11A & \multirow{2}{*}{ B11 } & B11A \\
\hline & & M11B & & $\mathrm{B} 11 \mathrm{~B}$ \\
\hline & \multirow{2}{*}{ M21 } & $\mathrm{M} 21 \mathrm{~A}$ & \multirow{2}{*}{ B21 } & B21A \\
\hline & & M21B & & B21B \\
\hline & \multirow{2}{*}{ M31 } & M31A & \multirow{2}{*}{ B31 } & B31A \\
\hline & & M31B & & B31B \\
\hline & Control (LDPE) & - & Control (waxed paper) & - \\
\hline \multirow{5}{*}{2017} & \multirow{2}{*}{ M12 } & M12A & \multirow{2}{*}{ B12 } & B12A \\
\hline & & M12B & & B12B \\
\hline & \multirow{2}{*}{ M42 } & M42A & \multirow{2}{*}{ B42 } & B42A \\
\hline & & M42B & & B42B \\
\hline & Control (LDPE) & - & Control (waxed paper) & - \\
\hline \multirow{2}{*}{2018} & M13 & M13B & B43 & B43B \\
\hline & Control (LDPE) & - & Control (waxed paper) & - \\
\hline
\end{tabular}


soils (agricultural field, meadow area and forest area), to a compost (as inoculum) produced by Gardea, in the best experimental conditions (1:23 inoculum/soil and $300 \mathrm{mg}$ of cellulose as reference material) to obtain the most effective substrate for the test. Samples for biodegradability were tested after milling with liquid $\mathrm{N}_{2}$. The test was carried out in glass desiccators of 2 - $3 \mathrm{~L}$ inner volume, airtight (diameter $200 \mathrm{~mm}$ ) in an overshadowed incubation chamber, with temperature monitoring at $26 \pm 2^{\circ} \mathrm{C}$.

\subsubsection{Soil collection and chemical analyses}

Soil samples (only for mulching), were collected from the upper layer $(20 \mathrm{~cm})$ of the areas where the plastics were placed in two dates: before their colocation, and after 4 months of harvest and incorporation of plastic into the soil using a tractor. Samples were collected randomly from each repetition of each block of plastics. Each sample included 8 sub-samples taken throughout the entire line. Total carbon and total $\mathrm{N}$ were determined on a LECO TruSpec C/N/S automatic elemental analyzer (St. Joseph MI, USA). Samples of soil were analysed for total macro- and micronutrient in the samples, after microwave digestion in $65 \%$ $\mathrm{HNO}_{3}$ using inductively coupled plasma-optical emission spectrometry (ICP-OES, model ICAP 6500 DUO THERMO).

\subsubsection{Quality parameters}

To evaluate the quality of tomatoes and peaches, destructive and non-destructive methods were used. 150 fruits per experimental unit were analyzed. Colour coordinates were determined using the CIELab colour space instrument with the aid of a spectrophotometer (Konica Minolta mod. CMS 700; Tokyo, Japan). Firmness was measured using non-destructive Acoustic Firmness Sensor (AWETA; Netherlands) for peaches and Durofel (Agrosta; Forges Les Eaux, France) for tomatoes. The firmness was also measured by destructive Magness-Taylor test using a digital penetrometer (Agrosta) with a tip diameter of $8 \mathrm{~mm}$ for peaches and of $4 \mathrm{~mm}$ for tomatoes and expressing the results as kg. Soluble solid content (SSC) as Brix degrees was determined in 10 samples by crushing the flesh and transferring the intact juice of the 10 samples to a digital refractometer (Atago mod. PR-101; Tokyo, Japan). Titratable acidity (TA) was measured by an automatic titrator (Mettler Toledo mod. G20 Compact Titrator; New York, NY, USA). Ten grams of juice from 10 fruits were diluted into $60 \mathrm{~mL}$ of distilled $\mathrm{H}_{2} \mathrm{O}$ and titrated with $0.1 \mathrm{~mol} \mathrm{~L}^{-1} \mathrm{NaOH}$ solution up to $\mathrm{pH} 8.1$, expressing the results as $\mathrm{g}$ of malic acid per kg.

\subsubsection{Statistical analysis}

All samples were analysed at least in triplicate each year. Statistical analyses were performed using a one-way ANOVA test and the significance of the difference between means was determined by Duncan's multiple range test $(p<0.05)$. Statistical analysis was performed using the Statistical Package for the Social Science (SPSS) software version 23.0 .

\section{RESULTS AND DISCUSSION}

\subsection{Mechanical properties}

The mechanical properties of bioplastics for mulching are showed in Table 2. In some cases, oligoelements made plastic processing more difficult, and consequently, it was necessary to increase the thickness. Sample M11 is much more elastic $(\varepsilon=552-615 \%)$ than the other ones tested, meanwhile mulching sample M31 was difficult to process due their low value of $\varepsilon$, ranging from $62 \%$ with oligoelements to $154 \%$ without them. Moreover, $\sigma$ is higher in biobased samples than in control sample and decreases with oligoelements in all cases. In the second year, M12 was the best bioplastic. Consequently, in general, M11 and M12 without oligoelements showed the best mechanical properties due to the high values of $E, \sigma$ and $\varepsilon$.

TABLE 2: Quality parameters of mulching plastic films.

\begin{tabular}{|c|c|c|c|c|c|c|}
\hline \multirow{2}{*}{ Year } & \multicolumn{2}{|c|}{ ВАTCH } & \multirow{2}{*}{$\begin{array}{l}\text { Thickness } \\
\qquad(\mu \mathrm{m})\end{array}$} & \multirow{2}{*}{$\begin{array}{c}\mathrm{E} \\
(\mathrm{Mpa})\end{array}$} & \multirow{2}{*}{$\begin{array}{c}\sigma \\
(\mathrm{Mpa})\end{array}$} & \multirow{2}{*}{$\begin{array}{c}\varepsilon \\
(\%)\end{array}$} \\
\hline & Material & Oligoelement Level & & & & \\
\hline \multirow{7}{*}{2016} & \multirow{2}{*}{ M11 } & M11A & $20(0)$ & $183(69)$ & $24.3(2)$ & $552(194)$ \\
\hline & & M11B & $38(4.1)$ & $55(10)$ & $8.3(2)$ & $615(117)$ \\
\hline & \multirow{2}{*}{ M21 } & M21A & $20(0)$ & $166(35)$ & $6(3)$ & $235(118)$ \\
\hline & & M21B & $30(0)$ & $108(29)$ & $5.4(1)$ & $214(73)$ \\
\hline & \multirow{2}{*}{ M31 } & M31A & $30(0)$ & $245(35)$ & $17.3(3)$ & $154(10)$ \\
\hline & & M31B & $30(0)$ & $127(25)$ & $12(4)$ & $62(54)$ \\
\hline & Control (LDPE) & - & $42(8)$ & $300(14)$ & $4.5(1)$ & $600(20)$ \\
\hline \multirow{4}{*}{2017} & \multirow{2}{*}{ M12 } & M12A & $31(1.5)$ & $190(55)$ & $25.5(1.8)$ & $430(90)$ \\
\hline & & M12B & $33(1.2)$ & $160(63)$ & $22.1(2.2)$ & $583(129)$ \\
\hline & \multirow{2}{*}{ M42 } & M42A & $51(4.9)$ & $137(60)$ & $6.4(2.9)$ & $247(88)$ \\
\hline & & M42B & $40(3.3)$ & $122(55)$ & $4.9(3.3)$ & $226(61)$ \\
\hline \multirow{2}{*}{2018} & Control (LDPE) & - & $12(2.6)$ & $187(20)$ & $26(3.8)$ & $280(39)$ \\
\hline & M13 & M13B & $22(2.0)$ & $220(42)$ & $34(7.3)$ & $310(40)$ \\
\hline
\end{tabular}

${ }^{1}$ The values between parentheses are the standard deviation. 
TABLE 3: Heavy metals ( $\mathrm{mg} \mathrm{kg}^{-1} \mathrm{dm}$ ) in mulching and bags samples (2016-2018).

\begin{tabular}{|c|c|c|c|c|c|c|c|c|c|c|c|c|c|}
\hline Metal & Control & M11A & M11B & M21A & M21B & M31A & M31B & M12A & B42A & B43B & M13B & $\begin{array}{c}\mathrm{DL} \\
\left(\mathrm{mg} \mathrm{kg}^{-1} \mathrm{dm}\right)\end{array}$ & $\begin{array}{c}\text { EN } 13432 \\
\left(\mathrm{mg} \mathrm{kg}^{-1} \mathrm{dm}\right)\end{array}$ \\
\hline Arsenic & $<\mathrm{DL}$ & $<\mathrm{DL}$ & $<\mathrm{DL}$ & $<\mathrm{DL}$ & $<\mathrm{DL}$ & $<\mathrm{DL}$ & $<\mathrm{DL}$ & $<\mathrm{DL}$ & $<\mathrm{DL}$ & $<\mathrm{DL}$ & $<\mathrm{DL}$ & 2.5 & 5 \\
\hline Cadmium & $<\mathrm{DL}$ & $<\mathrm{DL}$ & $<\mathrm{DL}$ & $<\mathrm{DL}$ & $<\mathrm{DL}$ & $<\mathrm{DL}$ & $<\mathrm{DL}$ & $<\mathrm{DL}$ & $<\mathrm{DL}$ & $<\mathrm{DL}$ & $<\mathrm{DL}$ & 0.19 & 0.5 \\
\hline Chromium & $<\mathrm{DL}$ & $<\mathrm{DL}$ & 0.70 & 1.33 & 1.5 & $<\mathrm{DL}$ & 0.77 & 1.88 & $<\mathrm{DL}$ & $<\mathrm{DL}$ & $<\mathrm{DL}$ & 0.5 & 50 \\
\hline Mercury & $<\mathrm{DL}$ & $<\mathrm{DL}$ & $<\mathrm{DL}$ & $<\mathrm{DL}$ & $<\mathrm{DL}$ & $<\mathrm{DL}$ & $<\mathrm{DL}$ & $<\mathrm{DL}$ & $<\mathrm{DL}$ & 0,358 & 0,426 & 0.3 & 0.5 \\
\hline Molybdenum & $<\mathrm{DL}$ & $<\mathrm{DL}$ & $<\mathrm{DL}$ & $<\mathrm{DL}$ & $<D L$ & $<D L$ & $<\mathrm{DL}$ & $<\mathrm{DL}$ & $<\mathrm{DL}$ & $<\mathrm{DL}$ & $<\mathrm{DL}$ & 0.5 & 1 \\
\hline Nickel & 1.15 & $<\mathrm{DL}$ & $<D L$ & $<\mathrm{DL}$ & $<D L$ & $<D L$ & $<\mathrm{DL}$ & 1.41 & $<\mathrm{DL}$ & $<\mathrm{DL}$ & $<\mathrm{DL}$ & 1 & 25 \\
\hline Lead & $<\mathrm{DL}$ & $<\mathrm{DL}$ & $<\mathrm{DL}$ & $<\mathrm{DL}$ & $<\mathrm{DL}$ & $<\mathrm{DL}$ & $<\mathrm{DL}$ & $<\mathrm{DL}$ & $<\mathrm{DL}$ & 0,514 & 0,86 & 2 & 50 \\
\hline Copper & 6.63 & $<\mathrm{DL}$ & 1.61 & $<\mathrm{DL}$ & 1.70 & $<\mathrm{DL}$ & 2.39 & $<\mathrm{DL}$ & $<\mathrm{DL}$ & $<\mathrm{DL}$ & 0,437 & 1 & 50 \\
\hline Selenium & $<\mathrm{DL}$ & $<\mathrm{DL}$ & $<\mathrm{DL}$ & $<\mathrm{DL}$ & $<\mathrm{DL}$ & $<\mathrm{DL}$ & $<\mathrm{DL}$ & $<\mathrm{DL}$ & $<\mathrm{DL}$ & $<\mathrm{DL}$ & 1,72 & 0.5 & 0.75 \\
\hline Zinc & $<\mathrm{DL}$ & 5.88 & 1360 & 7.18 & 1700 & 10.5 & 2010 & $<\mathrm{DL}$ & $<\mathrm{DL}$ & $<\mathrm{DL}$ & $<\mathrm{DL}$ & 5 & 150 \\
\hline Fluorine & $<\mathrm{DL}$ & $<\mathrm{DL}$ & $<\mathrm{DL}$ & $<\mathrm{DL}$ & $<\mathrm{DL}$ & $<\mathrm{DL}$ & $<\mathrm{DL}$ & $<\mathrm{DL}$ & $<\mathrm{DL}$ & 5,33 & 5,16 & 0.05 & 100 \\
\hline
\end{tabular}

For fruit protection bags the values obtained were also appropriate for their agriculture use (data not showed). It is remarkable that $\sigma$ and $\varepsilon$ were higher for the bags than for the mulching films. It means that loading the biodegradable matrix with carbon black and oligoelements decreased elongation and tensile strength at break values of the samples.

In addition, thickness was more variable, possibly due to processing problems in adjusting parameters for film blowing.

\subsection{Heavy metals and fluorine concentration of the biofilms}

The concentration of heavy metals and fluorine has been quantified in order to verify the compliance with the limits defined in the Standard EN 13432 for compostable packaging. The regulation limits in $\mathrm{mg} \mathrm{kg}^{-1}$ (dry mass) the quantity of certain heavy metals (Arsenic, Cadmium, Chromium, Mercury, Molybdenum, Nickel, Lead, Copper, Selenium and Zinc) and fluorine. The results showed that all metals and fluorine were below the detection limits of the technique with the exception of the Zinc element (Table $3)$. In 2016, the mulching samples that were additivated with higher concentration of $\mathrm{Zn}$, presented a value above the regulation limit of $150 \mathrm{mg} \mathrm{kg}^{-1}(\mathrm{dm})$. The amount of oligoelement added to the mulching was calculated for fertilization purposes, but in order for the plastics to be labelled as "OK biodegradable SOIL" the percentage had to be lower. Therefore, in 2017 the concentration of this element in plastic was reduced (data not showed), but once again, the values were over $150 \mathrm{mg} \mathrm{kg}^{-1}(\mathrm{dm})$. For fruit protection bags, all samples are below the allowed limit (data not showed).

\subsection{Biodegradation results}

Regarding biodegradation behaviour, in the soil selected for the tests, high percentages of biodegradability in soil were achieved. In 2016, $98-100 \%$ of biodegradation was observed after 176 days. These values are much ap-

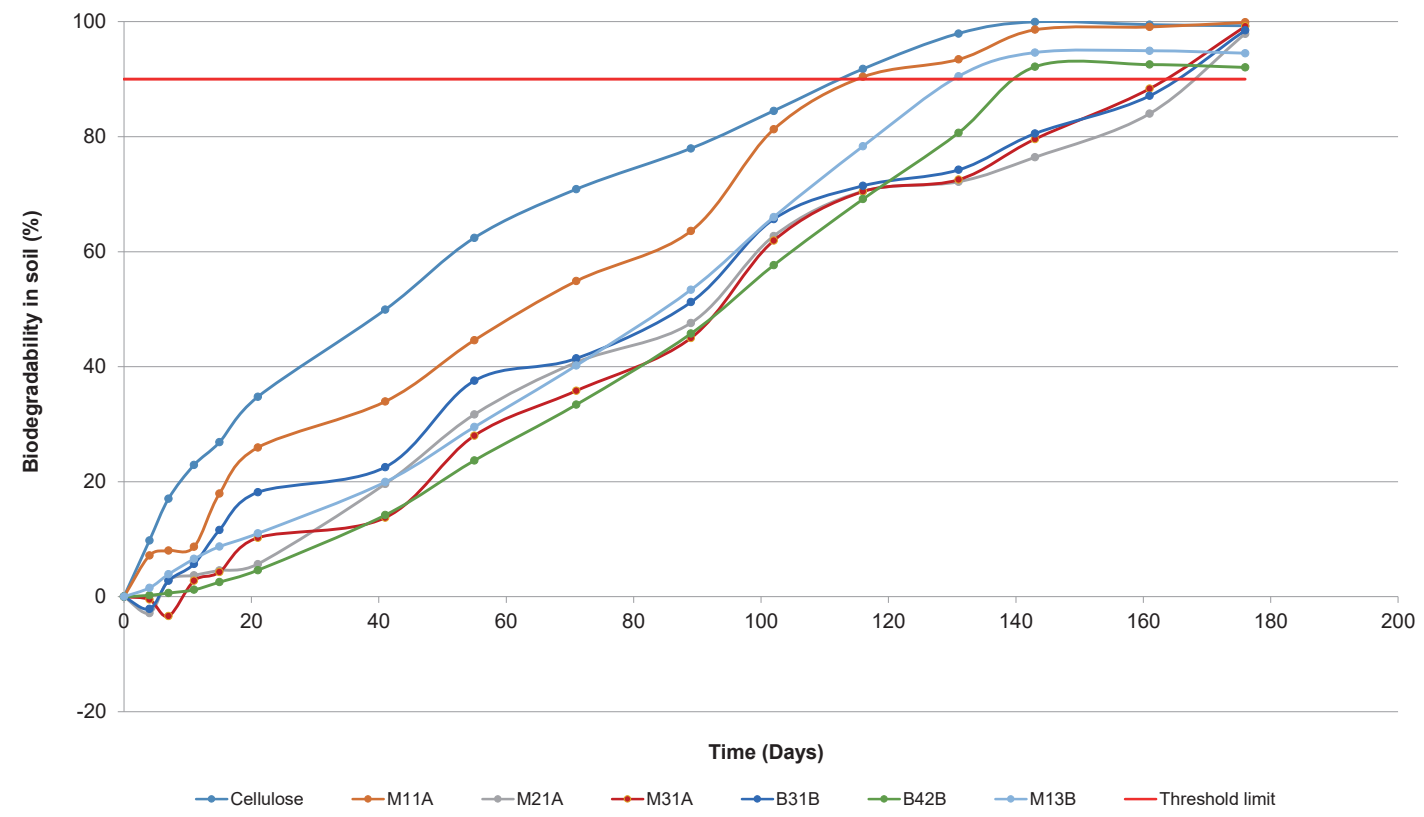

FIGURE 2: Percentages of aerobic biodegradation for each plastic material tested and the positive reference material. 
propriate considering that the "OK biodegradable SOIL" certification forces to obtain a degradation of more than $90 \%$ within two years. In Figure 2 shows the percentages of aerobic biodegradation for each plastic material tested and the positive reference material (Cellulose).

\subsection{Soil collection and chemical results}

For the soil analysis, the results for seasons 2016, 2017 and 2018 are shown in Figures 3 to 5. In 2016 season (Figure 3), an increase in the concentration of $\mathrm{Mn}$ and $\mathrm{Zn}$ was observed due to the use of bioplastics which contained the highest concentrations of these elements. This result shows that the oligolements are present in the soil after plastic degradation. For the macronutrients, the concentration of $\mathrm{P}$ and $\mathrm{K}$ in soil was higher when using our
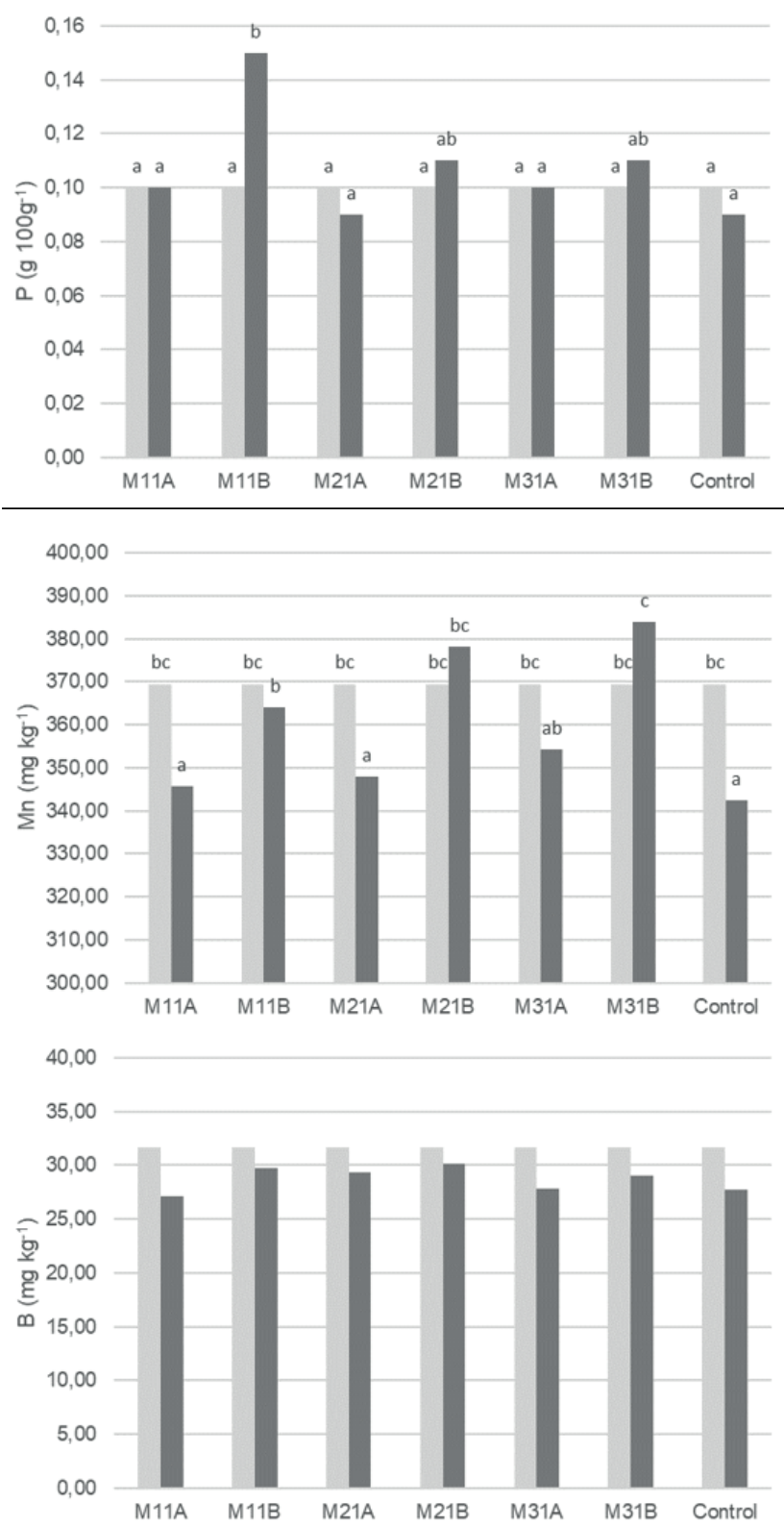

bioplastics than when using the control one, thus being more interesting to use bioplastics with added oligoelements.

In the second year (Figure 4), the oligoelement concentration showed an irregular behaviour. An increase in the concentration of $\mathrm{Mn}$ and $\mathrm{Zn}$ was observed in the bioplastics with these additives, but also in the control ones. Similar results were observed for Boron. This could be due to cross contamination when the plastic degrades in the soil. No effect was observed in the concentration of macronutrients. Finally, the relation $\mathrm{C} / \mathrm{N}$ decreased during the season, showing a positive effect of the incorporation of the bioplastics within the soil.

In the last season, in 2018 (Figure 5), several changes were observed regarding oligoelement concentrations.
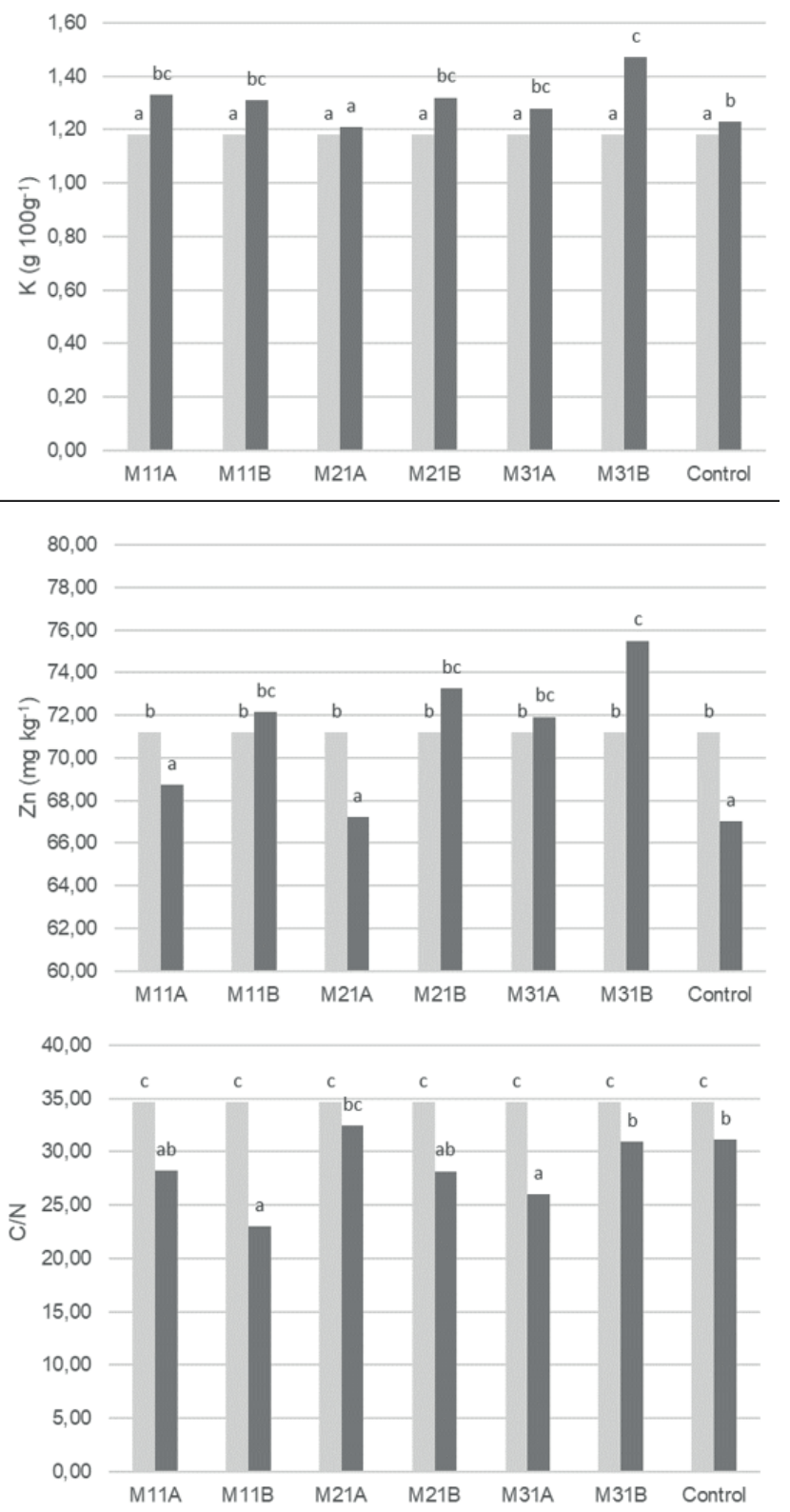

FIGURE 3: Concentrations of nutrients and oligoelements and relation $\mathrm{C} / \mathrm{N}$ before (light grey) and after (dark grey) incorporation into the soil of 6 bioplastics (3 different materials with 2 different concentrations of oligoelements each one) in season 2016 . Different letters indicate significant differences $(\mathrm{p} \leq 0.05)$ between treatments. 

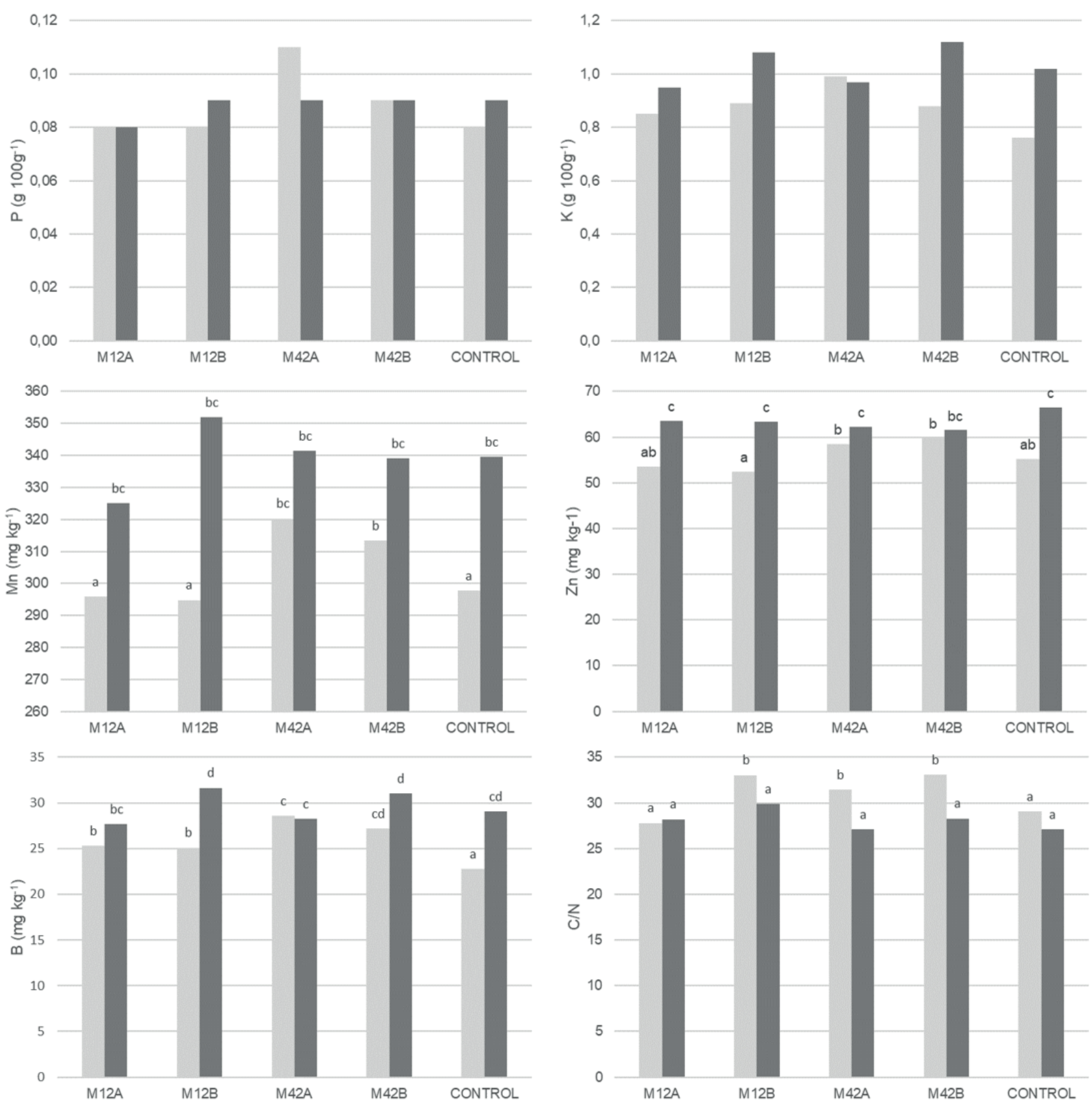

FIGURE 4: Concentrations of nutrients and oligoelements and relation C/N before (light grey) and after (dark grey) incorporation into the soil of 4 bioplastics ( 2 different materials with 2 different concentrations of oligoelements each one) in season 2017 . Different letters indicate significant differences $(\mathrm{p} \leq 0.05)$ between treatments.

First, an increase in the Boron's concentration was observed in both control and biodegradable plastic rows. This indicates that the Boron incorporated within the bioplastics is properly liberated. However, the increase that was also observed in the control rows could also be due to a cross contamination or the bioplastic being present from previous seasons. Such cross contamination could also be the cause of the increase in the amounts of $\mathrm{Mn}$ and $\mathrm{Zn}$. Moreover, the $\mathrm{C} / \mathrm{N}$ relation decreased with the time. This is a positive result because the recommended values for $\mathrm{C} / \mathrm{N}$ relation is around 15 and all the actions implemented in the field should aim to obtain these quantities.

\subsection{Quality parameters}

In 2016 season, although significant differences were observed, in the quality parameters of the crops, there was no clear pattern in the use of different plastics for tomatoes (Table 4). Therefore, the differences were due more to the intrinsic variability of the sample instead of the effect of the plastics on the crop.

In 2017 season, no differences were observed. The plastics did not have an effect on these quality parameters. The incidence of blossom end rot, a water-soaked spot located at the blossom end of tomato fruits, was higher in the control (18\%) than in the bioplastics M12 (7\%) and M42 $(8 \%)$. This result could be related to a different temperature 

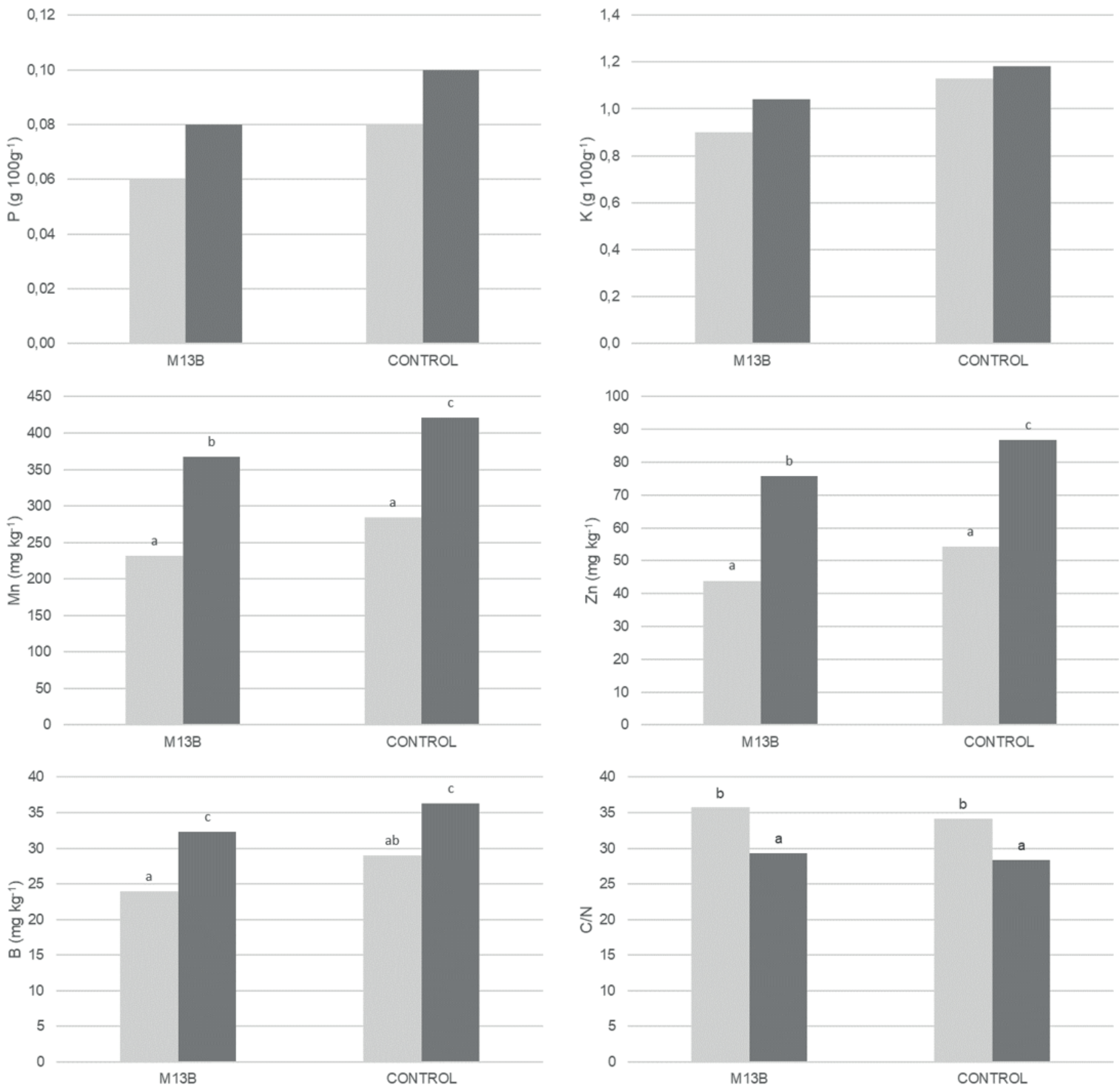

FIGURE 5: Concentrations of nutrients and oligoelements and relation C/N before (light grey) and after (dark grey) incorporation into the soil of 2 bioplastics ( 1 material with 2 different concentrations of oligoelements) in season 2018. Different letters indicate significant differences $(\mathrm{p} \leq 0.05)$ between treatments.

in the soil for each plastic or to different amount of reflected sunlight. More assays are necessary to confirm this hypothesis. Other tests carried out on tomatoes and peppers have also showed that fruit growth and quality gave very similar results when using biodegradable plastic or control mulch (Martín-Closas et al., 2008; Cowan et al., 2013), especially concerning total dry weight, soluble solids, colour and shape.

In 2018, statistically significant differences were observed in the weight and color parameters (coordinate $a^{\star}$ ). Fruits appeared larger and more reddish when cultivated on the new biodegradable plastic. As in the previous season, a greater incidence of physiopathies was observed in the plastic control of physiopathies, similar to the blossom end rot, specifically a cracking of the calicine zone of the fruit. Again, the biodegradable plastic showed a better performance, reaching a higher quality of the fruits. Figure 6 an example of the observed physiopathies can be seen. On the left, the tomatoes obtained with biodegradable mulching plastics can be seen and on the right, tomatos obtained with control mulching.

During the development of the fruit protection biobags, on one hand, we searched for fruits with homogeneous colour and, on the other hand, for fruits with quality parameters not affected by the use of biobags. In order to achive this, PW was incorporated to protect crops against UV rays and laser micro-perforations were done to the bottom of the bag to allow for the necessary elimination of water va- 
TABLE 4: Quality parameters in 'Manitu' tomato at harvest.).

\begin{tabular}{|c|c|c|c|c|c|c|c|c|}
\hline \multirow{2}{*}{ Year } & \multicolumn{2}{|r|}{ ВАТСН } & \multirow{2}{*}{ Firmness (kg) } & \multirow{2}{*}{ Durofel } & \multirow{2}{*}{ Weight (g) } & \multirow{2}{*}{ SSC ( ${ }^{\circ}$ Brix) } & \multirow{2}{*}{$a *(D 65)$} & \multirow{2}{*}{ Blossom end rot (\%) } \\
\hline & Material & Oligoelement Level & & & & & & \\
\hline \multirow{7}{*}{2016} & \multirow{2}{*}{ M11 } & M11A & $0.32 \mathrm{a}$ & $65.04 \mathrm{a}$ & $102.11 \mathrm{ab}$ & $6.73 c$ & $32.76 \mathrm{ab}$ & $<1$ \\
\hline & & M11B & $0.39 \mathrm{~d}$ & $68.18 \mathrm{~b}$ & 107.84 abc & $6.27 \mathrm{ab}$ & $34.17 \mathrm{c}$ & $<1$ \\
\hline & \multirow{2}{*}{ M21 } & M21A & $0.38 \mathrm{~cd}$ & $70.26 b$ & 97.97 a & $6.60 \mathrm{bc}$ & 31.69 a & $<1$ \\
\hline & & M21B & $0.38 \mathrm{bcd}$ & $68.90 \mathrm{~b}$ & $105.5 \mathrm{abc}$ & $6.23 a b$ & $33.12 \mathrm{bc}$ & $<1$ \\
\hline & \multirow{2}{*}{ M31 } & M31A & $0.39 \mathrm{~cd}$ & $63.62 \mathrm{a}$ & $113.42 \mathrm{c}$ & $5.93 \mathrm{a}$ & $31.99 \mathrm{ab}$ & $<1$ \\
\hline & & M31B & $0.34 \mathrm{abc}$ & $68.76 b$ & $102.54 \mathrm{ab}$ & $6.70 \mathrm{c}$ & $32.75 a b$ & $<1$ \\
\hline & Control & - & $0.33 \mathrm{ab}$ & 69.02 b & 110.42 bc & $6.73 \mathrm{c}$ & $33.22 \mathrm{bc}$ & $<1$ \\
\hline \multirow{5}{*}{2017} & \multirow{2}{*}{ M12 } & M12A & 0.44 bc & 68.06 & 143.75 & 6.47 & 32.24 & $7 a$ \\
\hline & & M12B & $0.48 \mathrm{c}$ & 70.72 & 140.33 & 6.3 & 32.51 & $7 a$ \\
\hline & \multirow{2}{*}{ M42 } & M42A & $0.43 \mathrm{bc}$ & 69.17 & 146.99 & 6.5 & 32.48 & $8 a$ \\
\hline & & M42B & $0.37 a$ & 69.21 & 128.58 & 6.53 & 31.23 & $8 a$ \\
\hline & Control & - & $0.41 \mathrm{ab}$ & 70.88 & 141.48 & 6.33 & 32.04 & $18 \mathrm{~b}$ \\
\hline \multirow{2}{*}{2018} & M13 & M13B & 0.57 & 78.12 & $101.05 b$ & 6.67 & $31.91 b$ & $12 b$ \\
\hline & Control & - & 0.59 & 79.56 & $74.17 \mathrm{a}$ & 6.21 & 29.48 a & $4 a$ \\
\hline
\end{tabular}

${ }^{1}$ different letters in the same column indicate significant differences $(p \leq 0.05)$ between treatments for the same year.

pour created during fruit ripening on trees. The use of this type of biobags did not affect the quality parameters of the peaches except for the colour (Table 5).

The use of biobags with PW caused a lower red coloration in the fruit and resulted in a lower coordinate $a^{*}$ value (from 14.88 to 16.05 without PW and from 12.39 to 14.49 with $\mathrm{PW}$ ) and a more homogeneous orange colour. These values were also lower than the control ones (16.40 and 15.37 for 2016 and 2017 season, respectively). The visual differences in colour can be observed in Figure 7. The differences observed in the rest of parameters may be due to intrinsic differences in crops instead of the difference in composition of the bioplastics and conventional plastics.

\section{CONCLUSIONS}

The following conclusions can be drawn from the study. In general, the biodegradable mulch showed appropiate mechanical properties for its placement as the conventional mulch, and the ability to resist all crop season. The bioplastic degradation into the soil increased the concentration of Manganese, Zinc and Boron. High biodegradation in soil was observed for all the bioplastics, althought the addition of $\mathrm{Zn}$ was not adequate to obtain the "OK biodegradable SOIL" certification. The use of biomulching in tomatoes decreased the incidence of blossom end rot and did not affect the rest of quality parameters. For peaches, the colour was more uniform in those grown with biodegradable bags when compared to those grown with tradicional bags, this being an important feature for fruit producers. Final biodegradable formulations for mulch and fruit protection bags have obtained the "OK Biodegradable SOIL" certification.

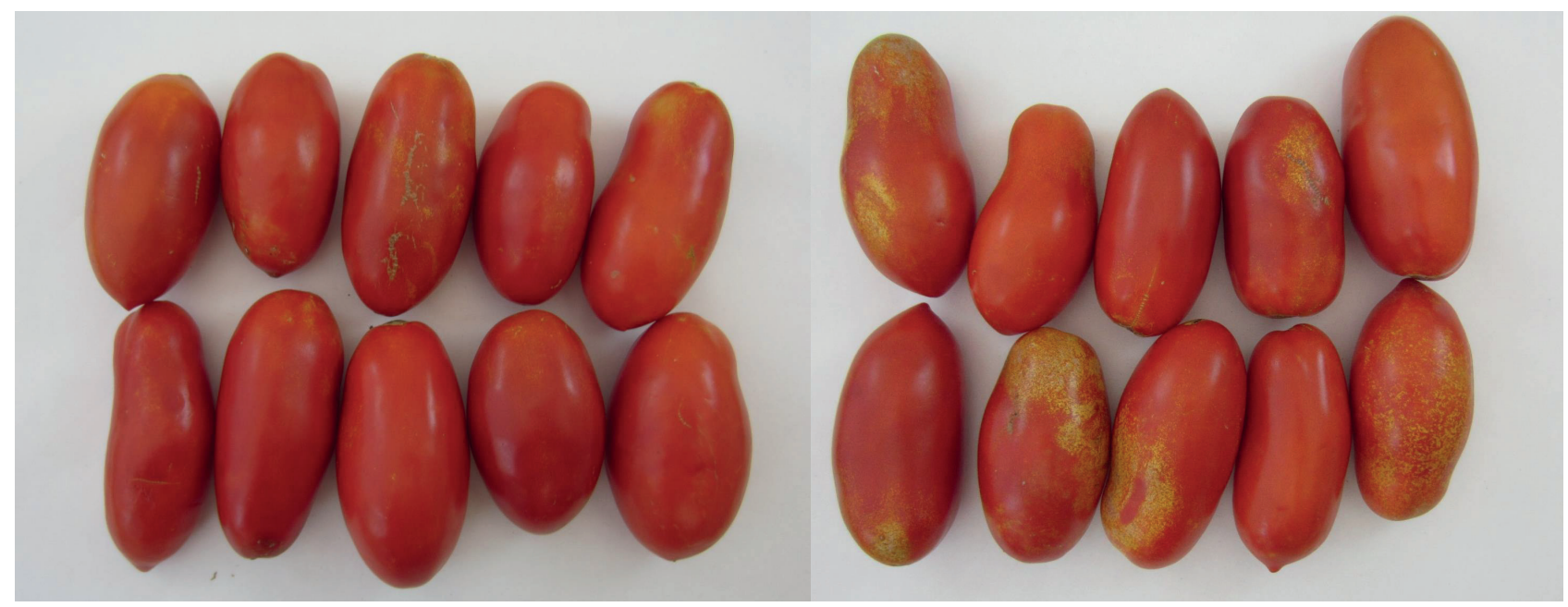

FIGURE 6: Tomatos obtained with Biodegradable mulching M31B (a) and tomatos produced with conventional plastic, control (b). 
TABLE 5: Quality parameters in '58GC' peach at harvest.

\begin{tabular}{|c|c|c|c|c|c|c|c|c|}
\hline \multirow{2}{*}{ Year } & \multicolumn{2}{|c|}{ ВАТСH } & \multirow{2}{*}{ Firmness (kg) } & \multirow{2}{*}{ Aweta } & \multirow{2}{*}{ Weight (g) } & \multirow{2}{*}{ T.A.(g.malic $L^{-1}$ ) } & \multirow{2}{*}{$\operatorname{SSC}\left({ }^{\circ}\right.$ Brix $)$} & \multirow{2}{*}{$a^{*}(D 65)$} \\
\hline & Material & PW & & & & & & \\
\hline \multirow{7}{*}{2016} & \multirow{2}{*}{ B11 } & B11A & 3.19 & 10.03 & 220.83 & $5.64 a b$ & $14.03 \mathrm{c}$ & $14.88 \mathrm{bc}$ \\
\hline & & B11B & 3.23 & 9.55 & 235.17 & $5.85 \mathrm{~b}$ & $14.58 \mathrm{c}$ & $14.49 a b$ \\
\hline & \multirow{2}{*}{ B21 } & B21A & 3.24 & 12.79 & 232.27 & $5.14 \mathrm{a}$ & $12.93 \mathrm{ab}$ & $15.76 \mathrm{bcc}$ \\
\hline & & B21B & 3.03 & 13.23 & 230.00 & $5.14 \mathrm{a}$ & $12.35 \mathrm{a}$ & $13.34 \mathrm{a}$ \\
\hline & \multirow{2}{*}{ B31 } & B31A & 3.20 & 8.81 & 207.53 & $6.02 b$ & $14.70 \mathrm{c}$ & $16.05 \mathrm{~cd}$ \\
\hline & & B31B & 3.23 & 12.87 & 221.30 & $5.51 \mathrm{ab}$ & $13.08 \mathrm{~b}$ & $13.16 \mathrm{a}$ \\
\hline & Control & - & 3.21 & 15.09 & 233.77 & $5.18 \mathrm{a}$ & $12.78 \mathrm{ab}$ & $16.40 \mathrm{~d}$ \\
\hline \multirow{5}{*}{2017} & \multirow{2}{*}{ B12 } & B12A & $2.56 \mathrm{~b}$ & $9.32 \mathrm{a}$ & 215.46 & $6.75 a$ & 13.43 & $15.45 \mathrm{c}$ \\
\hline & & B12B & $2.21 \mathrm{ab}$ & $9.64 \mathrm{ab}$ & 221.92 & $6.87 a$ & 13 & 14.14 b \\
\hline & \multirow{2}{*}{ B42 } & B42A & $2.06 \mathrm{a}$ & $11.63 \mathrm{abc}$ & 211.58 & $7.26 \mathrm{a}$ & 12.63 & $15.62 \mathrm{c}$ \\
\hline & & B42B & $3.62 c$ & $13.9 \mathrm{c}$ & 233.19 & $7.77 a$ & 12.6 & $12.39 \mathrm{a}$ \\
\hline & Control & - & $2.11 \mathrm{ab}$ & $11.88 \mathrm{bc}$ & 217.69 & $9.38 \mathrm{~b}$ & 13.13 & $15.37 \mathrm{c}$ \\
\hline \multirow{2}{*}{2018} & B43 & B43B & 2.49 & 13.77 & 299.59 & 5.47 & 13.48 & 16.77 \\
\hline & Control & - & 2.69 & 12.51 & 281.40 & 6.01 & 12.85 & 17.01 \\
\hline
\end{tabular}

different letters in the same column indicate significant differences $(p \leq 0.05)$ between treatments for the same year.
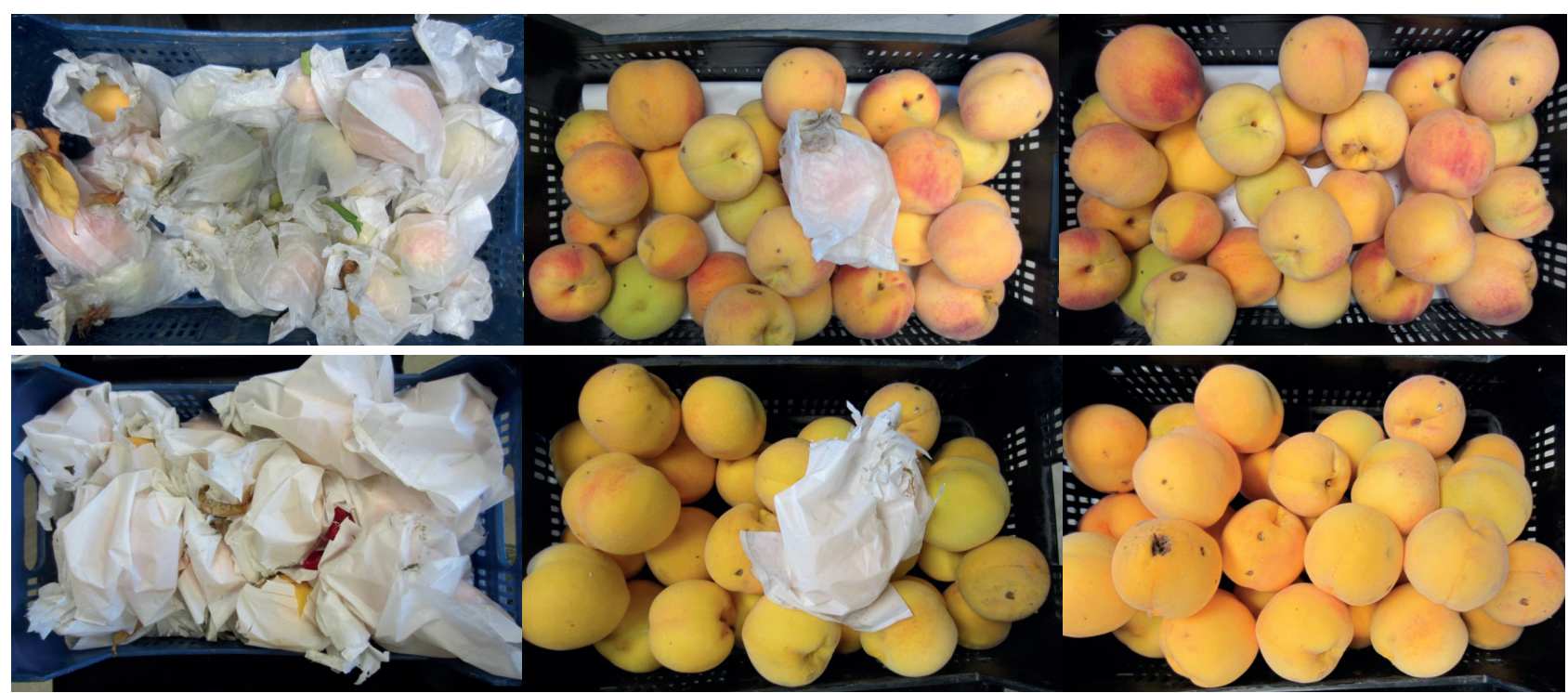

FIGURE 7: In first row, (a) peaches obtained with control bags and in the row below (b) peaches obtained with the biodegradable bags (B43B).

\section{AKNOWLEDGEMENTS}

The research leading to these results has received funding from the European LIFE Programme under the sub-program for environment and resource efficiency with a grant agreement $n^{\circ}$ LIFE14 ENV/ES/000486. Special acknowledgement to all project partners: AITIIP, ARCHA, CAA, EEAD-CSIC, GROENCREATIE, PCTAD and TRANSFER.

\section{REFERENCES}

Agricultural Films., 2017. Plasteurope.com

Cowan, J.S., Inglis, D.A., and Miles, C.A., 2013. Deterioration of three potentially biodegradable plastic mulches before and after soil incorporation in a broccoli field production system in Northwestern Washington. Hort Technology. 23 (6), 849-858.
European Commission, 2014. "Towards a Circular Economy".

Hernández, T., Chocano, C., Moreno, J.L., and García, C., 2016. Use of compost as an alternative to conventional inorganic fertilizers in intensive lettuce (Lactuca sativa L.) crops: Effects on soil and plant. Soil and Tillage Research. 160, 14-22. http://dx.doi. org/10.1016/j.still.2016.02.005.

Kader, M.A., Senge, M., Mojid, M.A., and Ito, K., 2017. Recent advances in mulching materials and methods for modifying soil environment. Soil and Tillage Research. 168, 155-166. http://doi.org/10.1016/j. still.2017.01.001.

Kasirajan, S., and Ngouajio, M., 2012. Polyethylene and biodegradable mulches for agricultural applications: a review. Agron. Sustain. Dev. 32, 501-529. http://doi.org/10.1007/s13593-011-0068-3.

Malinconico, M., Immirzi, B., Santagata, G., Schettini, E., Vox, G., and Mugnozza, G.S., 2008. An overview on innovative biodegradable materials for agricultural applications. In Progress in Polymer Degradation and Stability Research, H.W. Moeller, eds. (Nova Science Publishers), p. 69-114. 
Martín-Closas, L., Pelacho, A.M., Picuno, P., and Rodríguez, D., 2008. Properties of new biodegradable plastics for mulching, and characterization of their degradation in the laboratory and in the field. Acta Hortic. 801, 275-282. http://doi.org/10.17660/ActaHortic.2008.801.27.

Mormile, P., Petti, L., Rippa, M., Immirzi, B., Malinconico, M., and Santagata, G., 2007. Monitoring of the degradation dynamics of agricultural films by IR thermography. Polymer Degradation and Stability. 92, 777-784. http://doi.org/10.1016/j.polymdegradstab.2007.02.015.
Sharma, R.R., Reddy, S.V.R., and Jhalegar, M.J., 2014. Pre-harvest fruit bagging: a useful approach for plant protection and improved post-harvest fruit quality-a review. J. Hortic. Sci. Biotechnol. 89 (2), 101-113.http://doi.org/10.1080/14620316.2014.11513055

Steinmetz, Z., Wollmann, C., Schaefer, M., Buchmann, C., David, J., Tröger, J., Muñoz, K., Frör, O., and Schaumann, G.E., 2016. Plastic mulching in agriculture. Trading short-term agronomic benefits for long-term soil degradation? Science of the Total Environment. 550, 690-705.

Vitova, K., 2015. Plastic Films at the Root of Efficient and Sustainable Agriculture. In International Industry Conference on Silage, Mulch, Greenhouse and Tunnel Films Used in Agriculture, Barcelona, Spain. 